УДК 635.21:631.53.01:58.085

ИССЛЕДОВАНИЕ ЭФФЕКТИВНОСТИ РАЗЛИЧНЫХ СПОСОБОВ

СТЕРИЛИЗАЦИИ ЭКСПЛАНТОВ КАРТОФЕЛЯ

ПРИ МИКРОКЛОНАЛЬНОМ РАЗМНОЖЕНИИ

Лебедь М.Б., Берестнева Ю.В., Волков И.В., Бикметова К.Р., Лебедь Н.И.

ФГБНУ «Федеральный научный цฺентр агроэкологии, комплексных мелиораций и зашитного лесоразведения» Российской академии наук, Волгоград, е-mail: info@vfanc.ru

Авторами приведены результаты исследования влияния различных стерилизующих агентов, а также времени их обработки на жизнеспособность растительных эксплантов при микроклональном размножении картофеля сортов Импала и Ред Скарлетт. Исследования проводились на базе лаборатории биотехнологий ФНЦ агроэкологии РАН, а также ФГАОУ ВО ВолГУ. Исходным материалом являлись этиолированные ростки, полученные путем проращивания предварительно обработанных клубней картофеля в контролируемых условиях. Использованы такие стерилизующие агенты, как пероксид водорода, перманганат калия, этанол, в совокупности с пероксидом водорода, а также разбавленный раствор коммерческого препарата «Белизна» (активное вещество - гипохлорит натрия). Этиолированные ростки в условиях бокса биологической безопасности БМБ-II «Ламинар-C» NEOTERIC после химической стерилизации промывали в трех порциях стерильной дистиллированной воды. Экспланты, прошедшие стерилизацию, помещали в пробирки на питательную среду, приготовленную по прописи Мурасиге-Скуга, с добавлением регуляторов роста в количестве: 6-бензиламинопурин (6-БАП) - 1 мг/л, $\beta$-индолил-3-масляная кислота (ИМК) - 0,5 мг/л. Проанализировано влияние рассматриваемых веществ, а также времени их обработки на жизнеспособность эксплантов и их контаминацию. Кроме этого, было исследовано влияние антибиотика «Цефотаксим» на бактериальную контаминацию эксплантов при использовании тех же способов химической стерилизации. Установлено, что наилучшим режимом деконтаминации из рассмотренных способов является добавление в питательную среду антибиотика «Цефотаксим» в концентрации 350 мг/л с последующей обработкой 2,5\% раствором коммерческого препарата «Белизна» в течение 30 мин, обеспечивающим высокий выход стерильных жизнеспособных эксплантов (80\%).

Ключевые слова: микроклональное размножение, in vitro, стерилизация эксплантов, введение в культуру, картофель

\title{
STUDY OF VARIOUS METHODS EFFICIENCY FOR STERILIZING POTATO EXPLANTS AT MICROCLONAL REPRODUCTION
}

\author{
Lebed M.B., Berestneva Yu.V., Volkov I.V., Bikmetova K.R., Lebed N.I. \\ Federal State Budget Scientific Institution «Federal Scientific Center for Agroecology, \\ Complex Melioration and Protective Afforestation of the Russian Academy of Sciences», \\ Volgograd,e-mail:info@vfanc.ru
}

The authors present the study results of the effect of various sterilizing agents, as well as their processing time on the plant explants viability during microclonal propagation of potato varieties Impala and Red Scarlett. The studies were carried out in the biotechnological laboratory of the Federal State Budget Scientific Institution «Federal Scientific Centre of Agroecology, Complex Melioration and Protective Afforestation of the Russian Academy of Sciences», as well as the Volgograd State University. Etiolated seedlings obtained by pre-treated potato tubers germinating under controlled conditions were used as starting material. Hydrogen peroxide, potassium permanganate, ethanol in combination with hydrogen peroxide, as well as diluted solution of the commercial preparation «Belizna» (active ingredient is sodium hypochlorite) were selected as sterilizing agents. Etiolated seedlings after chemical sterilization were washed in three portions of sterile distilled water under the conditions of the biological safety cabinet BMB-II Laminar-S NEOTERIC. The sterilized explants were placed in test tubes on Murasige-Skoog nutrient medium with addition of growth regulators - 6-benzylaminopurine (6-BAP) ( $1 \mathrm{mg} / \mathrm{l}), \beta$-indole-3-butyric acid (IBA) $(0.5 \mathrm{mg} / \mathrm{l})$. The effect of the growth regulators, as well as the time of seedlings processing on the viability of explants and their contamination was analyzed. In addition, the Cefotaxime antibiotic effect on the explants bacterial contamination under using the same chemical sterilization methods was investigated. It was established that the addition of the Cefotaxime antibiotic in concentration of $350 \mathrm{mg} / \mathrm{l}$ to the nutrient medium with subsequent treatment with $2.5 \%$ solution of the commercial preparation «Belizna» for 30 minutes, was the best decontamination regimen of the considered methods, which provided a high yield of sterile viable explants $(80 \%)$.

Keywords: microclonal propagation, in vitro, explants sterilization, introduction to culture, potato

Картофель имеет большое значение в решении глобальной продовольственной проблемы, являясь важнейшей продовольственной культурой. Большое внимание уделяется оздоровлению семенного картофеля от вирусных болезней, снижающих урожайность культуры. Основным направ- лением получения оздоровленного посадочного материала является микроклональное размножение $[1,2]$, преимуществами которого также являются возможность получать высококачественный семенной картофель в условиях лаборатории круглый год в гораздо больших объёмах. В настоящее время 
в литературе имеются данные по микроклональному размножению картофеля [3], однако поиск эффективного способа стерилизации эксплантов всё ещё ведётся. Соблюдение условий стерильности в процессе микроклонального размножения культур, в том числе картофеля, является важнейшим фактором его успешного проведения. Растения обладают высокой восприимчивостью к микроорганизмам, подавляющим их рост, и не способны сопротивляться инфекциям. А поскольку питательная среда [4], на которой выращиваются экспланты, является идеальной средой для роста микроорганизмов, необходимо не только исключить возможность контаминации из внешней среды, но и обеспечить эффективную стерилизацию растительного материала, так как на его поверхности и внутри тканей почти всегда присутствует посторонняя микрофлора. Для этих целей применяют широкий спектр химических препаратов, однако стерилизующие агенты очень видоспецифичны и их выбор зависит от множества факторов: размер экспланта, наличие кожуры, плотность покровных тканей и др. Необходимо подобрать такие способы и режимы обработки экспланта, которые бы обеспечили его полную стерилизацию, не повредив при этом клеток и тканей растения. Целесообразно выбирать препараты, обладающие не только бактерицидной, но и фунгицидной, а также спороцидной активностью, что увеличивает эффективность стерилизации.

Цель исследования: подбор стерилизующего агента, а также оптимизация режимов стерилизации растительного материала (эксплантов картофеля сортов Импала и Ред Скарлетт).

\section{Материалы и методы исследования}

Экспериментальные исследования проводились в лаборатории биотехнологий ФНЦ агроэкологии РАН, а также в ФГАОУ ВО ВолГУ. Для проведения исследований были выбраны районированные и рекомендованные для выращивания в Волгоградской области сорта картофеля Импала и Ред Скарлетт, имеющие высокое продовольственное значение, благодаря низкому количеству в мякоти редуцирующих сахаров, что необходимо для производства чипсов и фри-продукции.

Целями данного исследования являлись подбор стерилизующего агента, а также оптимизация режимов стерилизации растительного материала по плану исследования, представленному в табл. 1. В качестве первичных эксплантов использовали этиолированные ростки картофеля изучаемых сортов. Для получения этиолированных проростков клубни картофеля тщательно промывали под проточной водой, удаляя поверхностные загрязнения мыльным раствором. Затем клубни обрабатывали слабым раствором перманганата калия в течение 20 мин, помещали в картонные коробки с перфорацией, дно которых было выстлано влажной фильтровальной бумагой, и проращивали при $25^{\circ} \mathrm{C}$ в течение 7-14 дней.

Таблица 1

Исследуемые способы и режимы стерилизации эксплантов

\begin{tabular}{|c|c|c|}
\hline $\begin{array}{c}\text { Стерилизую- } \\
\text { щий агент }\end{array}$ & $\begin{array}{c}\text { Содержание } \\
\text { активного } \\
\text { вещества }\end{array}$ & $\begin{array}{c}\text { Время } \\
\text { выдержки }\end{array}$ \\
\hline \multirow[t]{4}{*}{ «Белизна» } & \multirow[t]{2}{*}{$3 \%$} & 10 мин \\
\hline & & 20 мин \\
\hline & \multirow[t]{2}{*}{$2,5 \%$} & 20 мин \\
\hline & & 30 мин \\
\hline \multirow{2}{*}{$\begin{array}{c}\text { Этанол + пе- } \\
\text { роксид } \\
\text { водорода }\end{array}$} & \multirow[t]{2}{*}{$\begin{array}{c}95 \%\left(\mathrm{C}_{2} \mathrm{H}_{5} \mathrm{OH}\right) \\
3 \%\left(\mathrm{H}_{2} \mathrm{O}_{2}\right)\end{array}$} & $\begin{array}{c}15 \mathrm{c}\left(\mathrm{C}_{2} \mathrm{H}_{5} \mathrm{OH}\right), \\
15 \text { мин }\left(\mathrm{H}_{2} \mathrm{O}_{2}\right)\end{array}$ \\
\hline & & $\begin{array}{l}15 \mathrm{c}\left(\mathrm{C}_{2} \mathrm{H}_{5} \mathrm{OH}\right), \\
20 \text { мин }\left(\mathrm{H}_{2} \mathrm{O}_{2}\right)\end{array}$ \\
\hline \multirow{2}{*}{$\begin{array}{c}\text { Пероксид } \\
\text { водорода }\end{array}$} & \multirow[t]{2}{*}{$3 \%$} & 20 мин \\
\hline & & 30 мин \\
\hline \multirow{2}{*}{$\begin{array}{c}\text { Перманганат } \\
\text { калия }\end{array}$} & \multirow[t]{2}{*}{$10 \%$} & $30 \mathrm{c}$ \\
\hline & & $60 \mathrm{c}$ \\
\hline
\end{tabular}

От проросшего картофеля отламывали ростки длиной $2 . .4$ см, промывали под проточной водой с использованием хозяйственного мыла в течение 10 мин, освобождая материал от огрубевших наружных тканей и загрязнений, затем проводили химическую стерилизацию погружением в следующие агенты: 2,5...3\% раствор коммерческого препарата «Белизна» - 10...30 мин; $3 \%$ пероксид водорода - 15 и 20 мин с предварительным погружением в 95\%-ный этанол на 15 c; $3 \%$ пероксид водорода - 20 и 30 мин; 10\% раствор перманганата калия - 30 и 60 с.

Далее, в условиях бокса биологической безопасности БМБ-ІІ «Ламинар-С» NEOTERIC растительный материал промывали в трех порциях стерильной дистиллированной воды. Экспланты, прошедшие стерилизацию, помещали в пробирки на питательную среду, приготовленную по прописи Мурасиге-Скуга, с добавлением регуляторов роста в количестве: 6-бензиламинопурин (6-БАП) - 1 мг/л, $\beta$-индолил3 -масляная кислота (ИМК) - 0,5 мг/л. По окончании процесса пробирки с эксплан- 
тами размещали на полках климатической установки (КС-200) лаборатории биотехнологий ФГАОУ ВО ВолГУ, работающей в следующем режиме: освещенность 3000 лк, температура $+25^{\circ} \mathrm{C}$, относительная влажность воздуха $-70 \%$.

Работа в условиях ламинар-бокса, a также приготовление и автоклавирование питательных сред, подготовка посуды, обработка помещения, стерилизация посуды и инструментов проводились согласно общепринятым стандартам и методикам работы в асептических условиях [5]. Параллельно проводилась проверка стерильности условий проведения опыта: пробирку с питательной средой выдерживали в термостате при температуре $37^{\circ} \mathrm{C}$ в течение 48 ч. Учет количества асептических жизнеспособных, асептических нежизнеспособных, инфицированных растений проводился ежедневно на протяжении 14 дней.

Все эксперименты по определению эффективности влияния способа стерилизации эксплантов проводили в 100-кратной повторности. Статистический анализ проводили по общепринятым методикам [6].

\section{Результаты исследования и их обсуждение}

Оценка состояния исследуемых растений проводилась в течение двух недель со дня начала эксперимента посредством визуального осмотра. Для наглядного представления полученных результатов были отобраны 4 пробирки, внешний вид которых представлен на рисунке.

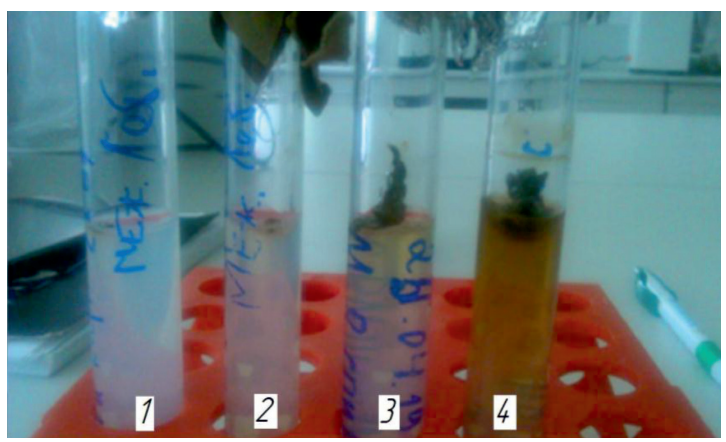

Общий вид эксплантов на 7 день культивирования:

1 - стерильныий жсизнеспособный эксплант, признаки заражения отсутствуют;

2 - стерильный нежизнеспособный эксплант, отмечено отмирание внешних тканей;

3 - нежизнеспособный эксплант с признаками бактериальной инфекиии; 4-нежсизнеспособньии эксплант, присутствует бактериальная и грибковая инфекиия, фенольное окисление питательной среды
Стерильные жизнеспособные экспланты отличались отсутствием признаков грибковых и бактериальных инфекций, а также активным ростом. Большинство таких образцов было получено при стерилизации раствором «Белизна» с концентрацией активного вещества (гипохлорит натрия) 2,5\% в течение 30 мин. Стерильные нежизнеспособные экспланты также характеризовались отсутствием контаминации, однако ткани такого образца приобретали темно-коричневый цвет уже на вторые сутки культивирования, рост останавливался, эксплант утрачивал жизнеспособность. Остальная часть образцов была контаминирована бактериями и грибками, изначально присутствовавшими в тканях экспланта ввиду недостаточно эффективной стерилизации. Грибковые и бактериальные культуры очень быстро подавляли рост экспланта, растение не могло справиться с инфекцией самостоятельно.

Стерильность условий проведения эксперимента была подтверждена экспериментально - при термостатировании пробы с питательной средой роста микроорганизмов обнаружено не было. В целом нами не установлено существенного влияния сорта картофеля на эффективность стерилизации эксплантов.

Учетным методом было подсчитано количество стерильных и инфицированных растений, а также тех эксплантов, что утратили жизнеспособность в результате химического ожога стерилизующим агентом. Результаты исследования приведены в табл. 2.

Наиболее мягким, но при этом эффективным способом стерилизации из рассматриваемых оказалось погружение в раствор «Белизна» с концентрацией активного вещества (гипохлорит натрия) 2,5 \% на 30 мин, при этом доля асептических жизнеспособных эксплантов составляет $70 \%$, в то время как применение Белизны с большей концентрацией активного вещества (3\%) в течение 20 мин характеризуется меньшим процентом выживаемости растений - $65 \%$ и отмиранием части эксплантов, что связано с гибелью растительных клеток под воздействием гипохлорита натрия.

Таким образом, применяя раствор коммерческого препарата «Белизна», целесообразно стремиться к снижению концентрации раствора, компенсируя это увеличением продолжительности стерилизации.

Ещё одним перспективным, на наш взгляд, способом было применение двух- 
ступенчатой стерилизации - погружение в 3\% раствор пероксида водорода с предварительной обработкой $95 \%$ этанолом в течение 15 с. Время выдержки в пероксиде водорода варьировалось от 15 до 20 мин ввиду малой токсичности вещества для растений и его быстрого разложения при последующем промывании дистиллированной водой. Однако процент выживаемости культур оказался очень низким: экспланты приобретали темно-коричневый цвет, останавливался их рост, на третьи сутки по- сле культивирования появлялись признаки грибковой инфекции.

Стерилизация материала исключительно пероксидом водорода по результатам исследования не отличается высокой эффективностью - 80\% эксплантов оказались инфицированы грибковыми культурами. При этом отсутствуют признаки отмирания тканей, что характеризует данный стерилизующий агент как щадящий и даёт перспективу его использования в совокупности с другими препаратами.

Таблица 2

Зависимость жизнеспособности и стерильности растений от способа стерилизации

\begin{tabular}{|c|c|c|c|c|}
\hline \multicolumn{2}{|c|}{ Способ стерилизации } & \multicolumn{3}{|c|}{$\begin{array}{c}\text { Количество растений, \% } \\
(\bar{X} \pm m)\end{array}$} \\
\hline $\begin{array}{c}\text { Стерилизующий агент/концен- } \\
\text { трация активного вещества }\end{array}$ & Время & $\begin{array}{c}\text { асептических, } \\
\text { жизнеспособных }\end{array}$ & $\begin{array}{l}\text { асептических, не- } \\
\text { жизнеспособных }\end{array}$ & $\begin{array}{l}\text { инфициро- } \\
\text { ванных }\end{array}$ \\
\hline \multirow[t]{2}{*}{ «Белизна» / 3\% } & 10 мин & $56 \pm 5,2$ & $19 \pm 2,3$ & $25 \pm 4,8$ \\
\hline & 20 мин & $36 \pm 1,9$ & $44 \pm 4,9$ & $20 \pm 2,5$ \\
\hline \multirow[t]{2}{*}{ «Белизна» / 2,5\% } & 20 мин & $65 \pm 8,6$ & $5 \pm 2,9$ & $30 \pm 7,6$ \\
\hline & 30 мин & $70 \pm 5$ & 0 & $30 \pm 4,7$ \\
\hline \multirow[t]{2}{*}{$\begin{array}{c}\text { Спирт этиловый / 95\% + пе- } \\
\text { роксид водорода / 3\% }\end{array}$} & $\begin{array}{c}15 \text { с }\left(\mathrm{C}_{2} \mathrm{H}_{5} \mathrm{OH}\right), \\
15 \text { мин }\left(\mathrm{H}_{2} \mathrm{O}_{2}\right)\end{array}$ & $31 \pm 3,8$ & $45 \pm 7,9$ & $24 \pm 9$ \\
\hline & $\begin{array}{l}15 \mathrm{c}\left(\mathrm{C}_{2} \mathrm{H}_{5} \mathrm{OH}\right), \\
20 \text { мин }\left(\mathrm{H}_{2} \mathrm{O}_{2}\right)\end{array}$ & $34 \pm 4,8$ & $43 \pm 5,2$ & $23 \pm 7,1$ \\
\hline Пероксид водорода / 3\% & 30 мин & $20 \pm 2,6$ & 0 & $80 \pm 8,4$ \\
\hline Перманганат калия / 10\% & $30 \mathrm{c}$ & $8 \pm 5,7$ & 0 & $92 \pm 3,8$ \\
\hline
\end{tabular}

При ме чан и е. Достоверно для $95 \%$-ного уровня вероятности. $* \bar{X}$ - средняя арифметическая, **m - ошибка средней арифметической.

Таблица 3

Оценка жизнеспособности и стерильности растений в зависимости от способа стерилизации с использованием цефотаксима (ЦФ)

\begin{tabular}{|c|c|c|c|c|c|}
\hline \multicolumn{3}{|c|}{ Способ стерилизации } & \multicolumn{3}{|c|}{$\begin{array}{c}\text { Количество растений, \% } \\
(\bar{X} \pm m)\end{array}$} \\
\hline $\begin{array}{c}\text { Стерилизующий агент/ } \\
\text { концентрация активного } \\
\text { вещества }\end{array}$ & $\begin{array}{l}\mathrm{C}_{\text {ЦФ, }}, \\
\text { мГ/л }\end{array}$ & Время & $\begin{array}{c}\text { асептических, } \\
\text { жизнеспособных }\end{array}$ & $\begin{array}{l}\text { асептических, не- } \\
\text { жизнеспособных }\end{array}$ & $\begin{array}{l}\text { инфициро- } \\
\text { ванных }\end{array}$ \\
\hline \multirow[t]{2}{*}{ «Белизна» / 3 \% } & \multirow[t]{2}{*}{350} & 10 мин & $69 \pm 5,9$ & $16 \pm 4,8$ & $15 \pm 2,9$ \\
\hline & & 20 мин & $40 \pm 7$ & $43 \pm 5,7$ & $17 \pm 8$ \\
\hline \multirow[t]{2}{*}{ «Белизна» / 2,5\% } & \multirow[t]{2}{*}{350} & 20 мин & $65 \pm 4,7$ & $4 \pm 2,9$ & $31 \pm 3,8$ \\
\hline & & 30 мин & $80 \pm 8,2$ & 0 & $20 \pm 5,8$ \\
\hline \multirow[t]{2}{*}{$\begin{array}{c}\text { Спирт этиловый / 95\% + пе- } \\
\text { роксид водорода / 3\% }\end{array}$} & \multirow[t]{2}{*}{350} & $\begin{array}{l}15 \mathrm{c}\left(\mathrm{C}_{2} \mathrm{H}_{5} \mathrm{OH}\right), \\
15 \text { мин }\left(\mathrm{H}_{2} \mathrm{O}_{2}\right)\end{array}$ & $34 \pm 4,6$ & $43 \pm 6,8$ & $23 \pm 6,4$ \\
\hline & & $\begin{array}{l}15 \mathrm{c}\left(\mathrm{C}_{2} \mathrm{H}_{5} \mathrm{OH}\right), \\
20 \text { мин }\left(\mathrm{H}_{2} \mathrm{O}_{2}\right)\end{array}$ & $38 \pm 2,6$ & $42 \pm 5,9$ & $20 \pm 4,9$ \\
\hline Пероксид водорода / 3\% & 350 & 30 мин & $24 \pm 1,9$ & 0 & $76 \pm 5,9$ \\
\hline Перманганат калия / 10\% & 350 & $30 \mathrm{c}$ & $11 \pm 4,8$ & 0 & $89 \pm 6,7$ \\
\hline
\end{tabular}

Пр и м еч ан и е. Достоверно для $95 \%$-ного уровня вероятности. $* \bar{X}-$ средняя арифметическая, **m - ошибка средней арифметической. 
Обработка эксплантов перманганатом калия не привела к успешному результату, эффективность данного способа в рамках нашего исследования крайне мала, доля инфицированных растений составила $92 \%$, имеет место фенольное окисление питательной среды. При этом стоит отметить необходимость использования большого объёма стерильной воды для промывания растительного материала от раствора перманганата калия, что неудобно в условиях ограниченной площади бокса микробиологической безопасности. Ввиду большого процента инфицированных растений было принято решение продолжить эксперимент с использованием дополнительной хемотерапии.

На втором этапе эксперимента для снижения бактериальной контаминации эксплантов предварительно в среду добавляли антибиотик цефотаксим в концентрации 250 мг/л. Выбор данного антибиотика был обусловлен отсутствием данных в научной литературе о влиянии цефотаксима на эффективность стерилизации растений in vitro. За основу была взята концентрация 350 мг/л, которая освещается в научной литературе как наиболее подходящая при сильном инфицировании растений [5]. Для этого в асептических условиях бокса в флакон с антибиотиком шприцом вводили стерильную дистиллированную воду, разводили до требуемой концентрации и добавляли антибиотик в колбу с питательной средой после автоклавирования, затем разливали среду по стерильным пробиркам. Для стерилизации эксплантов использовали те же стерилизующие агенты, что и на первом этапе эксперимента. Полученные результаты представлены в табл. 3.

Установлено, что добавление в питательную среду антибиотика «Цефотаксим» в концентрации 350 мг/л дает положительный эффект: наилучший результат зафиксирован при стерилизации эксплантов Белизной 2,5\% в течение 30 мин. При этом количество стерильных живых растений возросло на $10 \%$, а при использовании Белизны $3 \%$ в течение 10 мин - на $13 \%$. На эффективность стерилизации с помощью спирта, пероксида водорода и перманганата калия добавление антибиотика не оказало существенного влияния - процент инфицированных растений остался практически на том же уровне (в среднем - 3\% для перманганата калия, 4\% - для пероксида водорода, 3,5\% - для двухступенчатой стерилизации с помощью этанола и пероксида водорода).

\section{Заключение}

В настоящем исследовании применение раствора коммерческого препарата «Белизна» с концентрацией активного вещества (гипохлорит натрия) 2,5\% продолжительностью выдержки 30 мин обеспечивает высокую эффективность при стерилизации эксплантов картофеля, что выражается высоким выходом жизнеспособных растений (до $80 \%$ ). Добавление в питательную среду антибиотика «Цефотаксим» в концентрации 350 мг/л оказывает положительное влияние и увеличивает процент стерильных жизнеспособных растений на $3 \ldots 13 \%$, что является целесообразным. Осуществление данного способа стерилизации не требует значительных затрат времени, энергии и материальных средств, что позволяет его эффективно использовать при микроклональном размножении картофеля.

\section{Список литературы / References}

1. Милехин А.В., Рубцов С.Л., Бакунов А.Л., Дмитриева Н.Н., Вовчук О.А. Перспективы использования биотехнологических установок в безвирусном семеноводстве картофеля в Среднем Поволжье // Известия Самарского научного центра РАН. 2014. Т. 16. № 5(3). С. 1184-1191.

Milekhin A.V., Rubtsov S.L., Bakunov A.L., Dmitrieva N.N., Vovchuk O.A. Perspectives of Using of Biotech Installations in Virus-Free Potato Seed Production in the Middle Volga Region // Izvestia of Samara Scientific Center of the Russian Academy of Sciences. 2014. V. 16. № 5(3). P. 1184-1191 (in Russian).

2. Рубцов С.Л., Милехин А.В., Шевченко С.Н., Бакунов А.Л., Дмитриева Н.Н. Методика микроклонального размножения и производство оздоровленных миниклубеней в оригинальном семеноводстве картофеля в условиях высокой инфекционной нагрузки Самарской области // Известия Самарского научного центра Российской академии наук. 2017. T. 19. № 2(4). C. 650-658.

Rubtsov S.L., Milekhin A.V., Shevchenko S.N., Bakunov A.L., Dmitrieva N.N. Methods of microclonal reproduction and production of healthy miniclub in the original seed-growing of potatoes in conditions of high infectious load of the Samara region // Izvestia of Samara Scientific Center of the Russian Academy of Sciences. 2017. V. 19. № 2 (4). P. 650-658 (in Russian).

3. Кушнаренко С.В., Ромаданова Н.В., Аралбаева М.М., Матакова Г.Н., Бекебаева М.О., Бабисекова Д.И. Создание коллекции in vitro сортов и гибридов картофеля как исходного материала для криоконсервации // Биотехнология. Теория и практика. 2013. № 1. С. 28-33.

Kushnarenko S.V., Romadanova N.V., Aralbaeva M.M., Matakova G.N., Bekebaeva M.O., Babisekova D.I. Creating a collection of in vitro varieties and hybrids of potatoes as a starting material for cryopreservation // Biotechnology. Theory and practice. 2013. № 1. Р. 28-33 (in Russian).

4. Калинин Ф.Л., Сарнацкая В.В., Полищук В.Е. Методы культуры тканей в физиологии и биохимии растений. Киев: Наукова думка, 1980. 488 с.

Kalinin F.L., Sarnatskaya V.V., Polishchuk V.E. Methods of tissue culture in the physiology and biochemistry of plants. Kiev: Naukova Dumka, 1980. 488 p. (in Russian).

5. Дорошенко Н.П. Антибиотики при клональном микроразмножении винограда // Плодоводство и виноградарство юга России. 2016. № 37 (1). С. 126-143.

Doroshenko N.P. Antibiotics for clonal micropropagation of grapes // Fruit growing and viticulture in the south of Russia. 2016. № 37 (1). P. 126-143 (in Russian).

6. Лакин Г.Ф. Биометрия: Учебное пособие для биол. спец. вузов. 4-е изд., перераб. и доп. М.: Изд-во Высш. Школа, 1990.352 c.

Lakin G.F. Biometrics: A study guide for biol. specialist. universities. 4-th ed., Pererab. and add. M: Izd-vo Vyssh. Shkola, 1990.352 p. (in Russian). 